

\title{
Holding Company in the Iraqi Company Act (as Amended 2019)
}

\author{
Mohammed Omer Ali AL-JAF \\ Department of Law - University of Garmian \\ Kurdistan-Iraq \\ Ph.D. student at Ahmad Ibrahim Kulliyyah of Laws \\ International Islamic University Malaysia
}

\begin{abstract}
This paper analyzes the conception of the holding company and ways to hold follower companies. Accordingly, the methodology of the conducting this article depends on the library sources to explain company law in Iraq, in particular the Company Act no. 21 of 1997 and its amendment no. 17 of 2019, which add a new type of company that is of great concern for researchers. The results of this paper shed light on types of companies governed by the Company Act, as divided by jurists. The results inform suggestions for improved monitoring by public authorities of companies' activities in order to attain the targets of the company legal system in Iraq.
\end{abstract}

Keywords: Holding Company, Iraqi Company. 


\section{المجلة اللدولية اللعلوم الأسانية والإمتصاعية International Journal of Humanities and Social Sciences}

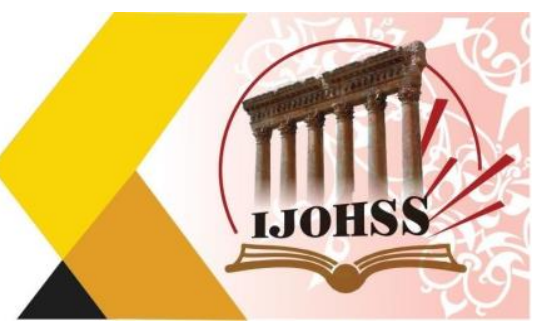

\section{RESEARCH BACKGROUND}

Companies are essentially formed to pool the money and resources of multiple parties, which entails legal organization of the rights and duties of complex personalities, including human beings and institutional formats, all bearing varying levels of risk. As a result, companies are subject to extensive jurisprudence with regard to determining legal personalities, and the activities they undertake. Some types of company are covered in the Iraqi Company Act 1997 (amended 2019), including the addition of the holding company. This paper explores the nature of the holding company under Iraqi company law.

\section{RESEARCH QUESTIONS}

1. What is the meaning of a company?

2. How can jurists divide types of company?

3. What is the meaning of the concept of holding company?

\section{RESEARCH OBJECTIVES}

1. Determining the meaning of the company according to the Iraqi Company Act no. 21 of 1997.

2. Limiting the types of the company by the divisions of jurists.

3. Clarify the holding company and the targets of its establishment.

\section{SCOPE AND LIMITATIONS}

This paper describes the meaning and types of company under the Iraqi legal system that are enforceable, but the difficulty of this research relates to the limited availability of English-language sources on the Iraqi legal system.

\section{RESEARCH METHODOLOGY}

This paper applies library research methods of legal analysis to clarify the nature of companies, particularly holding companies, under Iraqi law. The study is thus a deskbased inquiry utilizing library resources.

\section{STRUCTURE}

1. The meaning and definitions of company.

2. Determining the legal framework of the holding company.

3. Conclusion. 


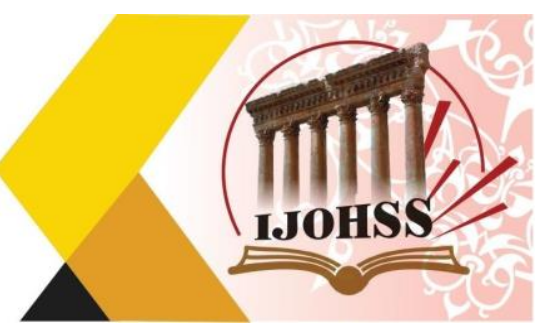

\section{COMPANY DEFINITION}

\subsection{Brief Overview of Iraqi Company Legal System}

As Kumani ${ }^{1}(2006)$ noted, business activities in Iraq prior to the colonial era were determined by the traditional formation of Iraqi company law under Ottoman civil law, such as the Commercial Act (1850), based on the Napoleonic Code (1807). Under the British occupation during WWI, Britain introduced the Indian Company Act of 1913 to extend British colonial governance to Iraq, based on the UK Company Act of 1906. This continued under the British Protectorate and formed the basis of company law in the independent Iraq, with the next major legislative reform occurring in the 1950s.

The Iraqi Civil Act no. 40 of 1951 had a special chapter for regular companies, which was abolished by the subsequent Company Act of 1957. A serious Act to Reform the Legal System, no. 35 of 1977, prepared the way for the Company Act no. 36 of 1983, which made huge provisions compared to the previous Iraqi Company Acts, targeting the establishment as well as the types of company. Company Act no. 21 of 1997 regulated the provision of private companies and abrogated previous acts, and the subsequent Act no. 22 of 1997 regulated the provision of public companies.

However, while notable in legislative terms, these Acts did not have a huge difference in practice. The most substantial change came in 2004 with the Coalition Provisional Authority Order no. 54 of 2004, published in the Iraqi Formal Gazette no. 3982 on June 2004, which fundamentally set the scene for company law in Iraq in the subsequent years.

\subsection{The Meaning of the Company}

According to the Iraqi Company Act no. 21 of 1997 (amended 2004) defines a company that as a contract whereby two persons or more abide to contribute in an economic project by submitting a quota of money or an operation to divide the profit, as well as the damage of the result of it among the partners. ${ }^{2}$ However, there are two exemptions of this definition whereby a company may be established by one person with unlimited responsibility, or with limited responsibility. ${ }^{3}$ So, according to the definition of the company, we can say that the company must have some features ${ }^{4}$ (Eutawi, 2005) $(\text { Yamulki, 2010) })^{5}$ :

1. A company is a contractual institution subject to the public conditions of the contract, such as consent, subjects, and reason.

\footnotetext{
${ }^{1}$ Kumani, L. J. (2006, July 31). alsharikat altijaria. dirasatan qanuniatan mqarnt. Retrieved from https://aoacademy.org: https://ao-academy.org/arabic/2006/07/496.html

${ }^{2}$ See art. 4, Iraqi Company Act, no. 21 of 1997.

${ }^{3}$ See art. 4, Iraqi Company Act, no. 21 of 1997.

${ }^{4}$ Eutawi, F. (2005). Alsharikat Altijariat fi Alqawanin Alwadeiat Walsharieat Al-Iislamia. Beirut, Lebanon: Manshurat Alhalbii Al-Huquqia.

${ }^{5}$ Yamulki, A. (2010). Alqanun Altijariu Alsharikat Dirasatan Mqarntan. Muscat, Oman: Dar Althaqafa.
} 


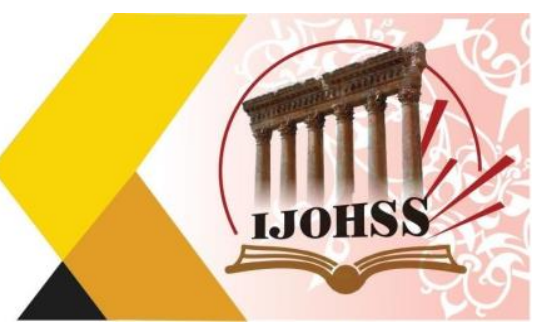

2. There are two or more parties who abide to participate in an economic project. Additionally, for the establishment of any kinds of a company, there must have two or more than two persons. However, the Iraqi Company Act no. 21 of 1997, amended 2004, allowed the establishment of a company by one person with limited or unlimited responsibility.

3. They must submit a quota of money or an operation, and the company may combine the skills with money, although there is no compulsory to submit skill and money by quota under the Iraqi Company Act no. 21 of 1997 (amended 2004), which allowed submission of a quota of talent and currency.

4. They have to divide which profit or damages they obtain from the company's activities.

\subsection{Division of Companies}

\subsubsection{Dividing companies according to the considerable personality}

This kind of division depends on the personal consideration by which the company was established. As a result, the company is divided according to personal matters, meaning that the personality of the partners can be considerably influential, while in monetary companies the wealth of the company is the paramount concern ${ }^{6}$ (Yamulki, 2010). In the personal company everyone might primarily focus on personal consideration of the partners, while in a monetary company the main concentration is on the wealth of the partners.

\subsubsection{Dividing companies according to legal and non-legal personalities}

There is another division of the companies whereby the company may attain legal personality due to being created by the partners according to national legal requirements, whereby the company automatically acquires a legal personality. Otherwise, some companies do not acquire legal personality because they were not established pursuant to enforced legislation, and the partners did not fulfil the requirements for company creation, albeit a company existed in reality ${ }^{7}$ (Sami, 2010). As a result, we can say that non-personality companies are not companies by law, because they do not meet the legal requirements.

1.3.3. Dividing companies according to trade features of partners and subject (trade or civil operations)

As noted by Eutawi (2005), there are two main types of company: civil and merchant.

Civil company: Relates to civil operations, created by partners who are not considered as traders. Likewise, the rules of the Commercial Act are not enforced on such companies,

\footnotetext{
${ }^{6}$ Yamulki, A. (2010). Alqanun Altijariu Alsharikat Dirasatan Mqarntan. Muscat, Oman: Dar Althaqafa.

${ }^{7}$ Sami, F. M. (2010). Alsharikat Altijariat Al'Ahkam Aleamat Walkhasa. Muscat, Oman: Dar Althaqafa.
} 


\section{المجلة اللحولية اللعلوم الآسانية والإمتاعية} International Journal of Humanities and Social Sciences

website:www.ijohss.com Email:editor@ijohss.com ISSN: 2415 - 4822
مارس 2021

Volume (19)
(19) العدا (19)

March 2021



and the partners do not receive trade features; as a result, rules related to normal citizenship are enforced on partners ${ }^{8}$ (Zanki, 2011).

Merchant company: This kind of the company can be considered as the most important, because of its role in the national and global economic system, undertaking significant trade activities, with partners acquiring the trade feature. Likewise, the rules of the Commercial Act are enforced on such companies ${ }^{9}$ (Zanki, 2011).

Civil and merchant companies have some fundamental separations in their activities, partnership features, and enforceable legislation. As a result, we can say that determining the figure of the company affects which legislation might be applicable to the company.

\subsubsection{Dividing companies into stock and quota companies}

This division depends on the consideration of the partners as well as dividing the wealth of the company. When the personality of partners is considerable and the wealth of the company is divided into quota, so that the types of the company are quota companies and vice-versa. As a result, when the personality of the partners is not considerable, and the wealth of the company is divided into shares, the type of company is a stock company ${ }^{10}$ (Yamulki, 2010).

\subsection{Basis of Analysis}

Having described the contract in the Iraqi Company Act and explained some divisions of companies, the types of company under the Iraqi Company Act no. 21 of 1997 can be defined based on the Iraqi company legal system and jurists' divisions of companies. According to the Iraqi Company Act, types of companies in Iraq include the following ${ }^{11}$ :

- Sharing (stock) company.

- Limited company.

- Person company with limited responsibility.

- Person company with unlimited responsibility (individual project).

- Solidarity company.

- Simplified company.

We can say that every current companies in Iraqi Company Act might adhere to one or more type of company as clarified previously information. In addition, it must be acknowledged that Iraq's company legal system underwent various stages if development, and acquired some issues along the way. Amendments of the Company Act in 2019 were published in the Iraqi Formal Gazette no. 4554 on September 2019, and

\footnotetext{
${ }^{8}$ Zanki, F. (2011). Sharike Musaheme fi Al-Qanun Al-Waz'i Wafiqh Al-Islami ta'sis eijra'at neshat (2 ed.). Muscat, Oman: Darul Nafa's Lilneshir Watawzie'.

${ }^{9}$ Zanki, F. (2011). Sharike Musaheme fi Al-Qanun Al-Waz'i Wafiqh Al-Islami ta'sis eijra'at neshat (2 ed.). Muscat, Oman: Darul Nafa's Lilneshir Watawzie'.

${ }^{10}$ Yamulki, A. (2010). Alqanun Altijariu Alsharikat Dirasatan Mqarntan. Muscat, Oman: Dar Althaqafa.

${ }^{11}$ See Iraqi Company Act, no. 21 of 1997.
} 


\section{اللمجلة اللحولية اللملوم الأنسانية والإمتامعية} International Journal of Humanities and Social Sciences website:www.ijohss.com Email:editor@ijohss.com ISSN: $2415-4822$

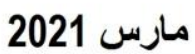

Volume (19)
(19) العدد (19)

March 2021

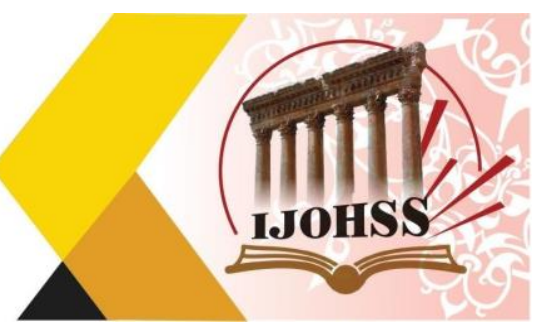

Act no. 17 of 2019 added another crucial type of company named the holding company (HC), which has existed around the world for years. This paper describes some of its provisions under the Iraqi Company Act, especially regarding following companies (FCs).

\section{HOLDING COMPANY (HC) CONCEPTS}

This section describes the definition of the meaning of the $\mathrm{HC}$ in terms of the targets of its establishment, and explains its obligations and prohibitions.

\subsection{Definition of $\mathrm{HC}$}

$\mathrm{HC}^{12}$ is a sharing or limited company that can dominate another company or sharing or limited company (FCs) in one of two ways:

- When it has more than half of the FC's capital and dominates its administration.

- When it dominates the council administration (e.g. board of directors) in the sharing (stock) company.

The name of the company must be added with the types of company as well as the word "holding", which must be written in all papers, announcements, statements, correspondence, and everything else issued by the HC. As a result, the name and the type of the $\mathrm{HC}$ must be emblazoned on everything issued by the company.

\subsection{Targets of the $\mathrm{HC}$}

The $\mathrm{HC}^{13}$ is supposed to participate in the backup of the national economy and jobs, including with regard to the following.

- Owning movable and immovable property in the framework of company activity

$\mathrm{HC}$ cannot have any kinds of property against company activities. In addition, the $\mathrm{HC}$ cannot have any illegal property, like drugs, according to the public order.

- Establishing FCs and managing them or participating in the administration of other companies that are sharing in them

This kind of target relates to the establishment of the $\mathrm{HC}$ in relation to the $\mathrm{FC}$.

- Investment of its money in stocks, instruments, and financial papers

- Supplement loaning, bailment, and financing of FCs

- Owning patents, trademarks, privilege rights, and other incorporeal rights, and exploiting rental factors of FCs or other than them

We can say that according to the amendment of the Iraqi Company Act, the $\mathrm{HC}$ has some opportunities to contribute more in commercial activities.

\footnotetext{
12 See art. 1, Act to Modify Iraqi Company Act, no. 21 of 1997.

${ }^{13}$ See art. 1, Act to Modify Iraqi Company Act, no. 21 of 1997.
} 
المجلة اللدولية اللعلوم الأسانية والإمتصاعية International Journal of Humanities and Social Sciences

website:www.ijohss.com Email:editor@ijohss.com ISSN: $2415-4822$
مارس 2021

Volume (19)
(19) العدا (19)

March 2021

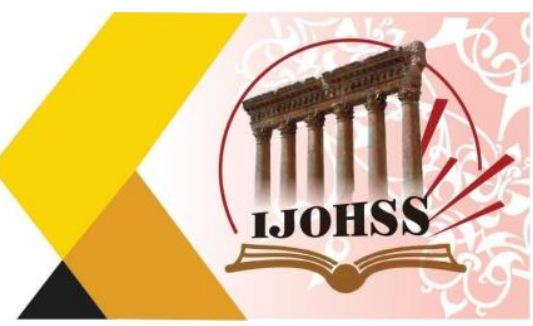

\subsection{Prohibition and Obligation}

Act no. 17 of 2019 to modify the Iraqi Company Act (Iraqi Company Act no. 21 of 1997) determined some prohibitions ${ }^{14}$ that the $\mathrm{HC}$ and the FCs had to undertake as much as they exist.

FCs cannot own the stocks in the $\mathrm{HC}$, and all activities causing the transmission of the possession of the stocks from the $\mathrm{HC}$ to the FC are null and void. According to this item, we can say that there is no percentage of $\mathrm{HC}$ stocks possessed by the FC.

The HC appoints its representative in the administration council in the FCs according to the percentage of participation, but the $\mathrm{HC}$ cannot share in the election of the other members of the council.

In addition, the HC must prepare a consolidated budget and a statement of profits and losses, both of itself and its FCs, according to international accounting measurements, in every financial year.

Moreover, the HC must obey the provisions of the Iraqi Company Act no. 21 of 1997 according to company type. In addition, for membership inside the company, ${ }^{15}$ according to the Iraqi Company Act no. 17 of 2019, all Iraqi real or juridical personalities can acquire membership in all companies as an establisher or stocker, unless they are not prevented from doing so because of their personality or features in being members of the Company by an Act or decision declared from a court or a specialty government entity. As a result, we can say that all types of personality can be a member inside the $\mathrm{HC}$, but there is an issue about foreign members of companies; when they have more than 50 percent in the $\mathrm{HC}$, they may have an influence on the national economy. Consequently, the Iraqi Company Act allows all foreign real or juridical personalities to acquire membership as an establisher or sharer in the sharing or limited company, provided that the percentage of the sharing Iraqi person must not be less than $51 \%$. We can say that the Iraqi Company Act observed that the foreign members may affect national economic development, so they determined the partnership percentage to favor nationals. The Iraqi Aliens Residents Act no. 76 of 2017 defined a "foreigner" as a person who does not have Iraqi identification.

\section{CONCLUSION}

\subsection{Results}

- A company under Iraqi provisions is essentially understood in terms of contractual arrangements, subject to public conditions of contract such as the consent, subjects, and reason.

- To establish a company there must be multiple persons, but a company can be established with one person as an exemption to the general provision.

${ }_{15}^{14}$ See art. 1, Act to Modify Iraqi Company Act, no. 21 of 1997. 
المجلة اللدولية اللعلوم الآنسانية والإمتماعية International Journal of Humanities and Social Sciences website:www.ijohss.com Email:editor@ijohss.com ISSN: $2415-4822$
مارس 2021

Volume (19)
(19)

March 2021

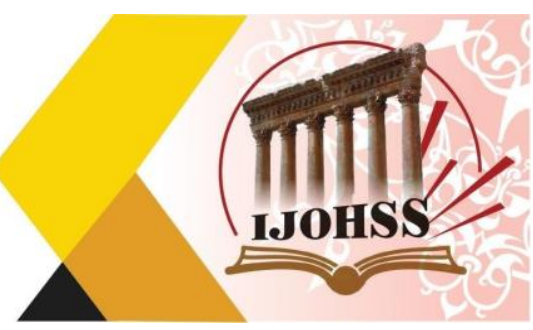

- The partnership of the company can submit a quota of money or operations or have no restriction, depending on the Iraqi Company Act.

- Profits or damages must be divided among company partners.

- In the personal company focus is on the personal consideration of the partners, while in monetary companies the main consideration is the wealth of the partners.

- The determining figure of the company affects the way in which the Act might be applicable to the company.

- Some companies do not acquire a juridical personality because they do not fulfil the requirements of the Act.

- There might be Acts which are applicable to companies depending on their figures.

- All the types companies mentioned by the Iraqi Company Act might take a figure or more than one, which are classified by the jurists.

- An HC must have more than half of the wealth of FCs, and dominate their administrative affairs or board of directors.

- An HC must adhere to its activities, and cannot have any kinds of property against the FC activities.

- There might be a broad term for the $\mathrm{HC}$ to participate in the commercial activities of the FC.

- Although there must be a strong relationship between HCs and FCs, the latter cannot have any percentage of ownership of the former's capital.

- Whether the real or juridical, a personality can be a member inside the HC.

- The Iraqi Company Act noticed the influences of foreigners on the national economy and restricted their participation.

\subsection{Recommendations}

- More powerful monitoring of companies is necessary to require regularization of their expected activities.

- Resources should be made available in different languages, with comparison of the Iraqi company legal system with foreign company legal systems. 
المجلة الدولية اللعلور الإنسانية والإمتاعية International Journal of Humanities and Social Sciences website:www.ijohss.com Email:editor@ijohss.com ISSN: $2415-4822$
مارس 2021

Volume (19)
(19)

March 2021

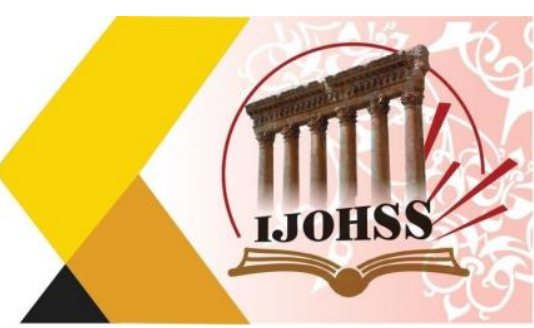

\section{REFERENCES}

1. Eutawi, F. (2005). Alsharikat Altijariat fi Alqawanin Alwadeiat Walsharieat AlIislamia. Beirut, Lebanon: Manshurat Alhalbii Al-Huquqia.

2. Kumani, L. J. (2006, July 31). alsharikat altijaria. dirasatan qanuniatan mqarnt. Retrieved from https://ao-academy.org: https://aoacademy.org/arabic/2006/07/496.html

3. Sami, F. M. (2010). Alsharikat Altijariat Al'Ahkam Aleamat Walkhasa. Muscat, Oman: Dar Althaqafa.

4. Yamulki, A. (2010). Alqanun Altijariu Alsharikat Dirasatan Mqarntan. Muscat, Oman: Dar Althaqafa.

5. Zanki, F. (2011). Sharike Musaheme fi Al-Qanun Al-Waz'i Wafigh Al-Islami ta'sis eijra'at neshat (2 ed.). Muscat, Oman: Darul Nafa's Lilneshir Watawzie'.

6. Iraqi Civil Act no. 40 of 1951.

7. Iraqi Company Act no. 21 of 1997.

8. Iraqi Aliens Residents Act no. 76 of 2017

9. Act no. 17 of 2019 to Amend the Iraqi Company Act no. 21 of 1997. 